\title{
Implications of Hereditary Origin on the Immune Phenotype of Mismatch Repair-Deficient Cancers: Systematic Literature Review
}

\author{
Lena Bohaumilitzky 1,2,3, Magnus von Knebel Doeberitz ${ }^{1,2,3}$, Matthias Kloor ${ }^{1,2,3}$ and \\ Aysel Ahadova 1,2,3,* \\ 1 Department of Applied Tumor Biology, Institute of Pathology, University Hospital Heidelberg, \\ 69120 Heidelberg, Germany; 1.bohaumilitzky@dkfz-heidelberg.de (L.B.); \\ magnus.knebel-doeberitz@med.uni-heidelberg.de (M.v.K.D.); Matthias.Kloor@med.uni-heidelberg.de (M.K.) \\ Clinical Cooperation Unit Applied Tumor Biology, DKFZ, 69120 Heidelberg, Germany \\ Molecular Medicine Partnership Unit (MMPU), University Hospital Heidelberg, 69120 Heidelberg, Germany \\ * Correspondence: aysel.ahadova@med.uni-heidelberg.de; Tel.: +49-6221-564159
}

Received: 8 May 2020; Accepted: 29 May 2020; Published: 4 June 2020

check for updates

\begin{abstract}
Microsatellite instability (MSI) represents one of the major types of genomic instability in human cancers and is most common in colorectal cancer (CRC) and endometrial cancer (EC). MSI develops as a consequence of DNA mismatch repair (MMR) deficiency, which can occur sporadically or in the context of Lynch syndrome (LS), the most common inherited tumor syndrome. MMR deficiency triggers the accumulation of high numbers of somatic mutations in the affected cells, mostly indel mutations at microsatellite sequences. MSI tumors are among the most immunogenic human tumors and are often characterized by pronounced local immune responses. However, so far, little is known about immunological differences between sporadic and hereditary MSI tumors. Therefore, a systematic literature search was conducted to comprehensively collect data on the differences in local $\mathrm{T}$ cell infiltration and immune evasion mechanisms between sporadic and LS-associated MSI tumors. The vast majority of collected studies were focusing on CRC and EC. Generally, more pronounced T cell infiltration and a higher frequency of B2M mutations were reported for LS-associated compared to sporadic MSI tumors. In addition, phenotypic features associated with enhanced lymphocyte recruitment were reported to be specifically associated with hereditary MSI CRCs. The quantitative and qualitative differences clearly indicate a distinct biology of sporadic and hereditary MSI tumors. Clinically, these findings underline the need for differentiating sporadic and hereditary tumors in basic science studies and clinical trials, including trials evaluating immune checkpoint blockade therapy in MSI tumors.
\end{abstract}

Keywords: colorectal cancer; DNA mismatch repair deficiency; immune evasion; immune infiltration; Lynch syndrome; microsatellite instability

\section{Introduction}

DNA mismatch repair (MMR) deficiency is a major pathway enabling genomic instability in human cancers. MMR deficiency is characteristic for $15 \%$ of colorectal cancers (CRC) and $30 \%$ of endometrial cancers (EC) (Figure 1a) [1]. MMR deficiency is caused by the inactivation of one of the MMR genes (MLH1, MSH2, MSH6 and PMS2). As a consequence of non-functional MMR, tumors accumulate insertion/deletion mutations at repetitive microsatellite sequence stretches and therefore present with the microsatellite instability (MSI) phenotype [2]. 

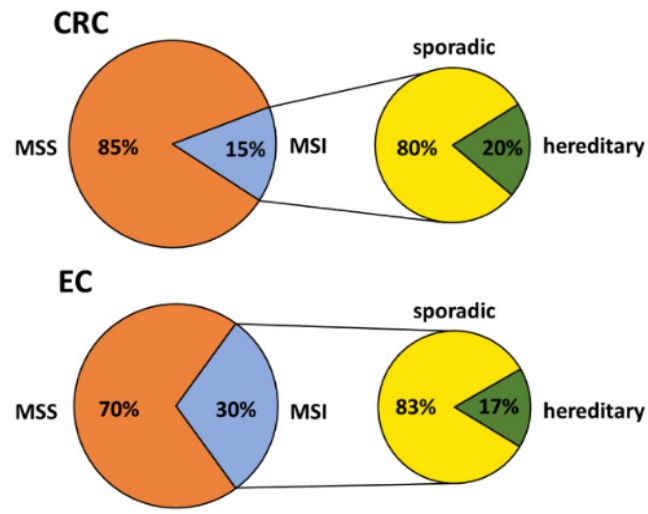

(a)

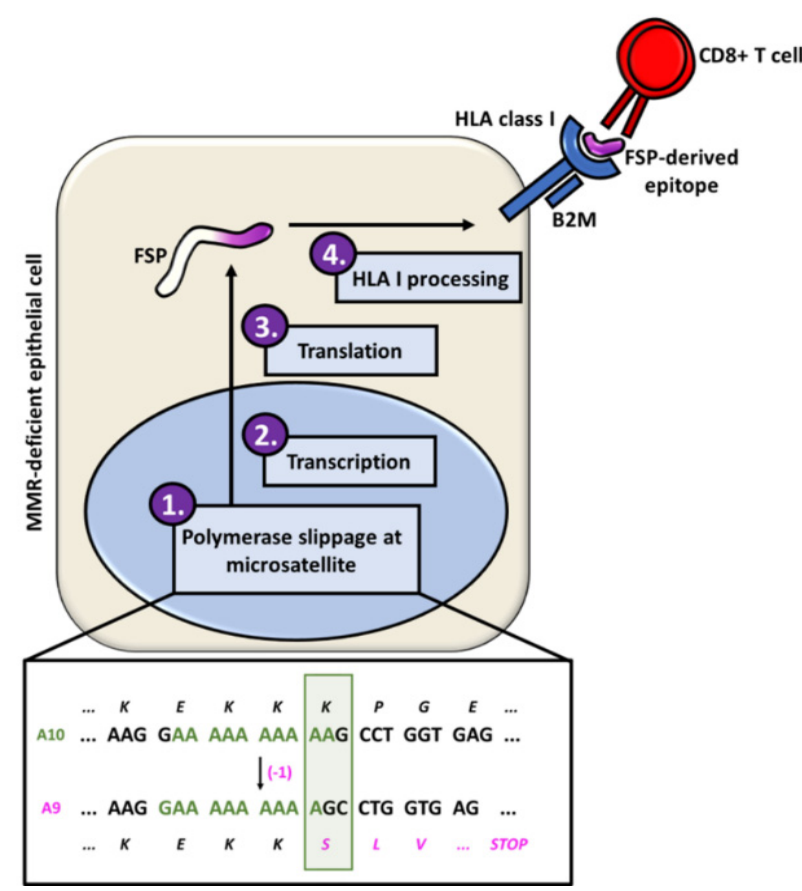

(b)

Figure 1. (a) Proportions of colorectal cancers (CRCs) and endometrial cancers (ECs) that present the microsatellite instability (MSI) phenotype and the respective percentages of MSI tumors with a hereditary background. (b) The generation of frameshift peptides (FSPs) starts with a polymerase slippage event in a microsatellite sequence that results in an insertion/deletion mutation. Due to the impaired mismatch repair (MMR) system, this error is not corrected and leads to a shift of the reading frame. After translation, the FSP is processed by the human leukocyte antigen (HLA) processing and presenting machinery (depicted: HLA class I) and FSP-derived neoantigens are presented on the surface of the MSI cell. Interaction of the HLA-bound antigen can trigger FSP-specific immune responses. The shown example is based on a mutation in the A10 microsatellite of the TGFBR2 gene.

Indel mutations at coding microsatellites (cMS) inactivate critical tumor suppressor genes and promote tumor development. Simultaneously, they can trigger shifts of the translational reading frame and lead to the generation of frameshift peptides (FSPs). FSPs play a major role in the pronounced immunogenicity of MSI CRCs as they often encompass long neopeptide stretches and multiple potential epitopes that can be recognized by the immune system (Figure 1b). FSPs are not only tumor-specific neoantigens but also shared by most MSI tumors, as they are the result of certain driver mutations that are positively selected during tumor evolution, e.g., the cMS tract in exon 3 of the TGFBR2 (transforming growth factor beta receptor 2) gene is mutated in around 90\% of MSI CRCs [2]. The immunogenicity of certain FSPs was comprehensively demonstrated in vitro [3-5].

Likely because of their high load of neoantigens, MSI cancers, typically those in the colorectum, display signs of high immunogenicity, such as pronounced local T cell infiltration [6-9], elevated counts of tumor-infiltrating lymphocytes (TILs) with cytotoxic potential [9-11] and a high frequency of immune evasion phenomena [2,12,13]. Patients with MSI CRCs also show a more favorable prognosis in a stage-wise comparison with microsatellite-stable (MSS) tumor patients, potentially reflecting active anti-tumor immune responses [14,15]. Notably, treatments supporting the anti-tumoral immune response, such as the recently developed immune checkpoint blockade (ICB) therapy, showed great success specifically in patients with metastasized MSI cancers $[16,17]$.

Although these clinical and immunological observations have been documented by several independent studies, little attention has been attributed to the influence of the origin of MSI cancers on their immunogenicity: Whereas the majority of MSI CRCs develop sporadically, mostly due to hypermethylation of the MLH1 promoter leading to MLH1 silencing [18-22], about $20-30 \%$ of MSI 
CRCs (Figure 1a) have a hereditary background and are associated with Lynch syndrome (LS), the most common inherited CRC syndrome [23]. LS is caused by an inherited monoallelic germline alteration inactivating one of the MMR gene alleles and leading, upon a second somatic hit, to the molecular phenotype of MMR deficiency in the affected cells [24,25].

The overall lifetime cancer risk in LS depends on the affected MMR gene and is estimated to vary between $50 \%$ and $80 \%$ for the high penetrance genes, MLH1 and MSH2 [26-32]. Clinically, LS CRC patients typically present with cancer onset at a younger age ( $\sim 5$ years) compared to sporadic MSI CRC patients [27]. Due to the high lifetime cancer risk associated with LS, carriers often, but not always, fulfill clinical criteria indicative of hereditary cancer such as young age of onset or multiple cancer manifestations (Bethesda criteria) [33,34].

There are profound differences in the pathogenesis of sporadic and hereditary MSI CRCs. Whereas sporadic MSI tumors predominantly arise through BRAF-mutated serrated lesions [35,36], LS-associated CRCs have been described to arise either through conventional adenomas [37-39] or through MMR-deficient crypt foci (MMR-DCF) [40-43]. MMR-DCF lack the expression of MMR proteins but, in contrast to adenomas, are morphologically undistinguishable from normal colonic crypts. MMR-DCF are specifically associated with LS and found in abundance in the intestinal mucosa of LS carriers (about 1 per $1 \mathrm{~cm}^{2}$ ) [41]. Recently, evidence for the true precancerous nature of MMR-DCF has emerged, including the molecular observation of MSI and mutations in cMS (e.g., HT001, AIM2, $B A X, T G F B R 2)$ in larger MMR-DCF [41,42]. The ongoing, FSP-associated immune surveillance in LS mutation carriers would potentially enable the elimination of most MMR-deficient cell clones.

Based on the differences between LS and sporadic MSI tumorigenesis, it seems plausible that the distinct evolutionary forces shaping the tumors are also reflected in phenotypic differences. However, evidence supporting this hypothesis has so far been scarce and scattered across the scientific literature. To the best of our knowledge, no comprehensive literature analysis comparing immune characteristics of LS and sporadic MSI tumors exists yet. In the present systematic literature review, we aim to comprehensively describe the local immune phenotype of MSI tumors, with emphasis on differences between LS-associated and sporadic MSI tumors. The existence of such differences would provide new insights into the role of immune surveillance in LS-associated and sporadic MSI cancers and guide therapeutic approaches in these molecularly distinct tumor types.

\section{Methods}

\subsection{Systematic Literature Search}

A systematic literature search was conducted to identify studies that compared the extent of immune infiltration and immune evasion in sporadic and hereditary MSI CRCs. The inclusion criteria were direct comparison of immune characteristics between sporadic and LS-associated MSI tumors, irrespective of tumor location and evaluation method. Exclusion criteria were comparison between MSS and MSI only, not considering hereditary or sporadic pathogenesis of MSI tumors, as well as lack of clear definition of the comparison groups.

An online MEDLINE search (http://www.pubmed.com) was conducted between 29 February and 10 March, 2020 and the following keywords were used: \{Lynch\} OR \{Lynch syndrome\} OR \{HNPCC\} OR \{MSI\} OR \{microsatellite instability\} OR \{MMR-deficient\} OR \{MMR-deficiency\} OR \{hereditary MSI\} OR \{sporadic MSI\} OR \{microsatellite instable\} OR \{RER + \} OR \{mutator phenotype\} AND \{immune infiltration\} OR \{immune microenvironment\} OR \{T cell infiltration\} OR \{TIL\} OR \{tumor infiltration $\}$ OR \{immune evasion\} OR \{T cell density $\}$ OR $\{$ B2M $\}$ OR $\{$ RFX5 $\}$ OR \{CIITA $\}$ OR $\{$ HLA $\}$ OR $\{$ TAP $\}$ OR \{NLRC5\}.

The screening of retrieved literature was performed manually. In addition, search of studies cited in the manuscripts that were analyzed on the full text level was performed. Although sample overlap between some of the analyzed studies cannot be formally excluded, sample collection from different sources or substantial temporal separation/analysis of different immune markers in the studies with 
mutual sources argues against major influence of the sample overlap on the results. A subset of the original search results was analyzed by two observers independently. The inter-rater reliability was measured by the Cohen's kappa coefficient using Rstudio [44]. The strength of agreement on the title level was found to be substantial $(\kappa=0.7)$. The status of the few studies with discrepant evaluation was unanimously agreed on by both observers when abstracts were analyzed.

Identified studies were checked for their eligibility by screening title, abstract and, lastly, the full text article. During the screening process, Preferred Reporting Items for Systematic Reviews and Meta-Analyses (PRISMA) recommendations were followed (Figure 2). The selected papers were analyzed qualitatively and quantitatively whenever possible. Quantitative analysis of the immune infiltration data was not conducted as different antibodies and counting methods (percentage of positive staining vs. cell counts) were used, and different cell categories (e.g., stromal vs. epithelial) were assessed. Additional studies and review articles addressing the immune phenotype of MSI CRCs were identified manually and independently of the used search terms from the authors' own files.

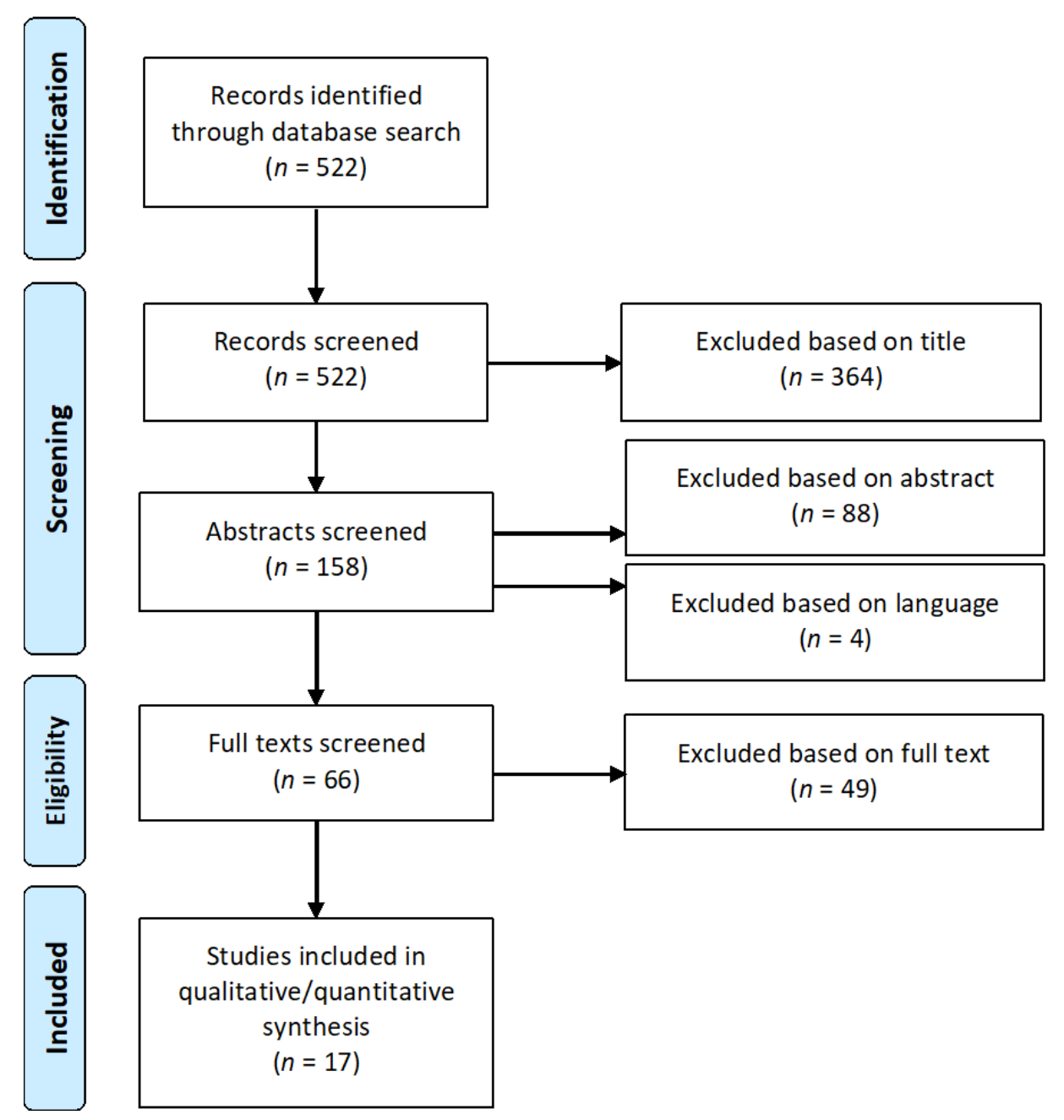

Figure 2. Flow diagram illustrating the systematic literature search according to Preferred Reporting Items for Systematic Reviews and Meta-Analyses (PRISMA) recommendations. The selection process identified 17 studies that were included in the analysis.

\subsection{Statistical Analysis}

All statistical evaluations were performed in GraphPad Prism (Version 6.07, GraphPad Software Inc., La Jolla, CA USA) and Rstudio (Version 3.6.1, RStudio Inc., Boston, MA USA) [44]. The 95\% confidence interval (CI) of the proportion of B2M mutations in the hereditary and sporadic MSI CRC 
groups was calculated with the modified Wald method in GraphPad Prism. Fisher's exact test $(\alpha=0.05)$ was used to check for a statistically significant association between $B 2 M$ mutations and the origin of the MSI CRC; the analysis was also performed in GraphPad Prism. Odds Ratios (OR) and respective 95\% CIs for the hereditary vs. the sporadic MSI CRC group were calculated and illustrated using the Rstudio packages epitools [45] and ggplot2 [46] Subsequently, statistical significance was checked using a Fisher's exact test $(\alpha=0.05)$.

\section{Results}

\subsection{Outcome of the Systematic Literature Search}

The literature search with the defined keywords covering immune infiltration and immune evasion (see Methods) revealed 522 articles in total. Following PRISMA recommendations, all articles $(n=522)$ were screened, and 364 publications were excluded based on the title. From the remaining 158 articles, 88 were excluded based on the abstract and 49 were excluded on the basis of the full text (Supplementary Table S1). 17 eligible articles fulfilled the criteria and were included in the final analysis. The selection process is visualized in Figure 2. The majority of identified studies focused on MSI CRC, whereas only a small proportion of studies analyzed MSI EC.

\subsection{Immune Infiltration in Hereditary and Sporadic MSI CRCs}

We first compared the immune infiltration determined by the quantitative analysis of different immune markers (CD3, CD4, CD8, PD1, PD-L1, FoxP3, CD45) between hereditary and sporadic MSI cancers. Seven studies [47-53] were informative for quantitatively evaluating the extent of local immune infiltration in MSI CRCs (Table 1). We looked at the results from the immunohistochemical analysis of different $\mathrm{T}$ cell subsets of these studies, where a total of 122 hereditary MSI CRC and 145 sporadic MSI CRC samples were examined. A direct comparison between hereditary and sporadic MSI CRC groups was performed in each study. The remaining ten studies that did not provide exact $\mathrm{T}$ cell counts but worked with frequencies or defined categories are not included in Table 1 but will be discussed below.

Studies using the pan-T cell marker CD3 for assessing intraepithelial $\mathrm{T}$ cell infiltration in sporadic and hereditary MSI CRCs uniformly observed higher T cell counts in the hereditary group [47,48]. Equivalently, Young et al. (2001) reported a higher frequency of $\mathrm{T}$ cell infiltration in the hereditary group (73\%) compared to the sporadic MSI CRC group (56\%) [54]. Further, a study by Jass et al. (2002), which was identified independently of the literature search, also mentions a higher frequency of Crohn's like reactions and peritumoral T cells in hereditary compared to sporadic MSI CRCs [55]. However, Takemoto et al., who did not use exact numbers for intraepithelial $\mathrm{T}$ cells but instead distinguished between poor, moderate and severe intraepithelial $\mathrm{T}$ cell infiltration, found no significant difference between the two groups [49]. Similarly, Wang et al., using hematoxylin and eosin slides to quantify $\mathrm{T}$ cell infiltration, did not find a significant difference between sporadic and hereditary MSI CRCs [56].

In addition to pan-T cell counts, some studies differentiated between $T$ cell subpopulations. For instance, Takemoto et al. reported slightly higher numbers of CD8- and CD4-positive T cells in the stroma of hereditary compared to sporadic MSI tumors [49]. However, other studies observed similar CD8 and CD4 infiltration levels in both MSI CRC groups [50,51,57]. 
Table 1. Summary of papers quantitatively evaluated for T cell immune infiltration in hereditary and sporadic MSI CRCs, colorectal adenomas and ECs. The number of patient samples, LS status, applied T cell markers and quantification results are displayed; the respective counting methods are indicated. The T cell counts are given separately for tumor epithelium and stroma. Asterisk represents statistically significant differences between the hereditary and sporadic group. hpf $=$ high-power-field.

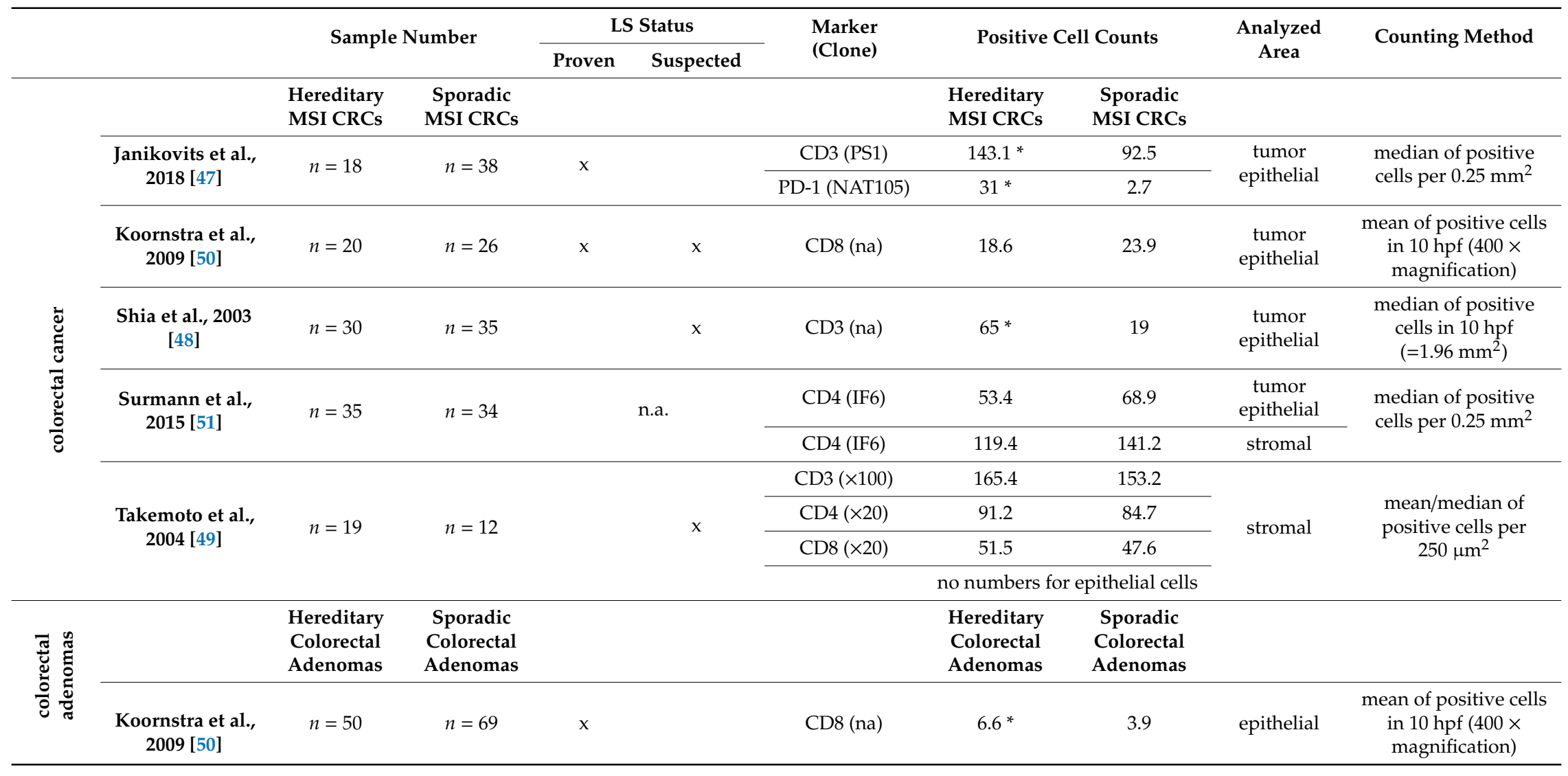


Table 1. Cont.

\begin{tabular}{|c|c|c|c|c|c|c|c|c|c|c|}
\hline & & \multirow{2}{*}{\multicolumn{2}{|c|}{ Sample Number }} & \multicolumn{2}{|c|}{ LS Status } & \multirow{3}{*}{$\begin{array}{l}\text { Marker } \\
\text { (Clone) }\end{array}$} & \multirow{2}{*}{\multicolumn{2}{|c|}{ Positive Cell Counts }} & \multirow{3}{*}{$\begin{array}{l}\text { Analyzed } \\
\text { Area }\end{array}$} & \multirow{3}{*}{ Counting Method } \\
\hline & & & & \multirow[t]{2}{*}{ Proven } & \multirow[t]{2}{*}{ Suspected } & & & & & \\
\hline \multirow{19}{*}{ 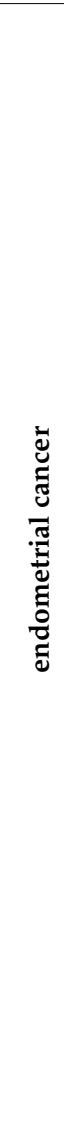 } & & $\begin{array}{l}\text { hereditary } \\
\text { MSI ECs }\end{array}$ & $\begin{array}{l}\text { sporadic } \\
\text { MSI ECs }\end{array}$ & & & & $\begin{array}{l}\text { hereditary } \\
\text { MSI ECs }\end{array}$ & $\begin{array}{l}\text { sporadic } \\
\text { MSI ECs }\end{array}$ & & \\
\hline & \multirow{8}{*}{$\begin{array}{l}\text { Pakish et al., } \\
2017 \text { [52] }\end{array}$} & \multirow{8}{*}{$n=20$} & \multirow{8}{*}{$n=38$} & & \multirow{8}{*}{$\mathrm{x}$} & CD3 (SP7) & 84.3 & 84.6 & \multirow{4}{*}{ stromal } & \multirow{8}{*}{$\begin{array}{l}\text { median of positive } \\
\text { cells per } 1 \mathrm{~mm}^{2}\end{array}$} \\
\hline & & & & & & CD4 (4B12) & 16.3 & 22.1 & & \\
\hline & & & & & & CD8 (4B11) & $82.8^{*}$ & 34.2 & & \\
\hline & & & & & & PD-L1 (E1L3N) & 289.3 & 297.9 & & \\
\hline & & & & & & CD3 (SP7) & 18.7 & 30 & \multirow{4}{*}{$\begin{array}{l}\text { tumor } \\
\text { epithelial }\end{array}$} & \\
\hline & & & & & & CD4 (4B12) & 2.8 & 8.6 & & \\
\hline & & & & & & CD8 (4B11) & 8.2 & 4.2 & & \\
\hline & & & & & & PD-L1 (E1L3N) & 4.8 & 8.2 & & \\
\hline & \multirow{10}{*}{$\begin{array}{l}\text { Ramchander } \\
\text { et al., } 2020 \text { [53] }\end{array}$} & \multirow{10}{*}{$n=25$} & \multirow{10}{*}{$n=33$} & \multirow{10}{*}{$\mathrm{x}$} & & CD3 (F7.2.38) & 590 & 617 & \multirow{10}{*}{$\begin{array}{l}\text { invasive } \\
\text { margin }\end{array}$} & \multirow{10}{*}{$\begin{array}{l}\text { mean of positive cells } \\
\text { per } 200 \mu \mathrm{m}^{2}\end{array}$} \\
\hline & & & & & & CD8 (C8/144B) & 291 & 233 & & \\
\hline & & & & & & $\begin{array}{l}\text { CD45RO } \\
\text { (UCLH1) }\end{array}$ & 597 & 653 & & \\
\hline & & & & & & $\begin{array}{c}\text { FoxP3 } \\
(236 \mathrm{~A} / \mathrm{E} 7)\end{array}$ & 72 & 58 & & \\
\hline & & & & & & PD-1 (NAT105) & $156^{*}$ & 108 & & \\
\hline & & & & & & CD3 (F7.2.38) & 386 & 241 & & \\
\hline & & & & & & CD8 (C8/144B) & $287^{*}$ & 116 & & \\
\hline & & & & & & $\begin{array}{l}\text { CD45RO } \\
\text { (UCLH1) }\end{array}$ & $548^{*}$ & 296 & & \\
\hline & & & & & & $\begin{array}{c}\text { FoxP3 } \\
(236 \mathrm{~A} / \mathrm{E} 7)\end{array}$ & 61 & 28 & & \\
\hline & & & & & & PD-1 (NAT105) & $118 *$ & 49 & & \\
\hline
\end{tabular}




\subsection{Immune Infiltration in Hereditary and Sporadic Pre-malignant Colorectal Lesions}

In summary, the existing literature provides ample evidence that LS-associated MSI CRCs generally have a more pronounced local T cell infiltration compared to sporadic MSI CRCs (Figure 3). Although the evidence level is lower and further research is warranted, enhanced immune cell reactivity in LS-associated lesions seems to be already present at a premalignant stage.

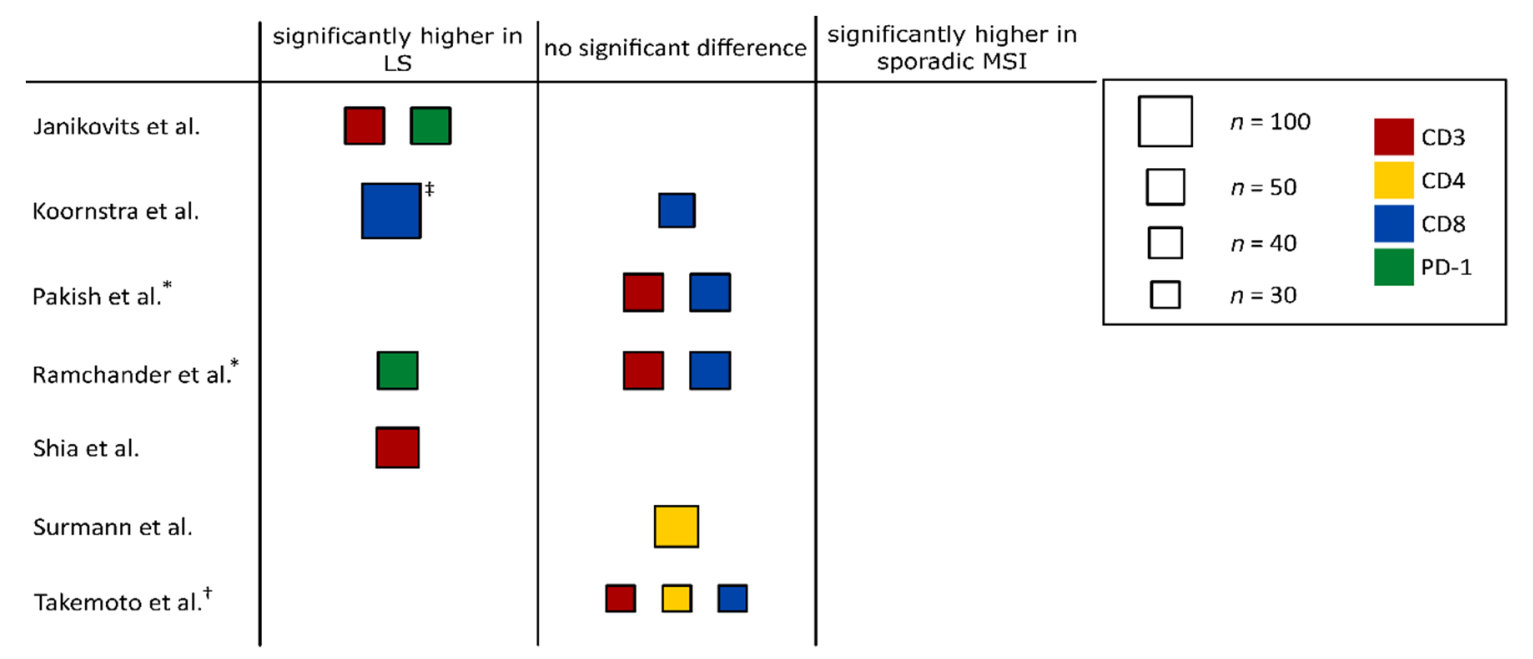

Figure 3. Graphical summary of the immune infiltration data in hereditary and sporadic MSI tumors. Studies that were assessed quantitatively were divided into three groups: studies reporting significantly higher immune infiltration counts in LS-associated MSI tumors compared to sporadic MSI tumors ("significantly higher in LS"), studies finding no significant differences between hereditary and sporadic MSI tumors ("no significant difference") and studies reporting significantly higher immune infiltration counts in sporadic MSI tumors ("significantly higher in sporadic MSI"). Study size is proportional to the box area, and color indicates the respective marker. + study only counted immune cells in stromal regions. $\ddagger$ data for colorectal adenomas. * studies that analyzed MSI ECs.

Our literature search identified a few studies analyzing immune infiltration not only in manifest cancers, but also in cancer precursors. Koornstra et al. (2009) reported significantly higher CD8-positive $\mathrm{T}$ cell counts in LS-associated compared to sporadic adenomas; however, the MSI status of these adenomas was not specified. Notably, T cell infiltration of LS-associated adenomas was significantly lower than the T cell infiltration of LS-associated CRCs [50]. Fittingly, another study [58] reported a higher frequency of T cell infiltration in LS-associated, MMR-deficient adenomas, compared to sporadic adenomas. However, as sporadic adenomas are mostly MMR-proficient, one should be careful when comparing LS-associated adenomas to this control group. An indication for activation of the immune system in premalignant lesions of LS patients has also been reported by Chang et al. who found increased RNA expression levels of CD4, IFNG, LAG3, PDL1, IL12A and TNF in LS-associated compared to Familial Adenomatous Polyposis (FAP)-associated adenomas suggesting immune activation in LS-associated adenomas. Interestingly, the authors reported that this immune profile was not related to the MMR status and mutational rates [59]. Further experiments are required to validate these findings and to provide visualization of immune cells infiltrating LS-associated adenomas.

Alongside with the direct assessment of $\mathrm{T}$ cell infiltration, the immune status of a lesion can be elucidated from other indirect markers of immune response, such as expression of immune checkpoint molecules or lymphocyte recruitment markers. The expression of PD-L1, an interferon-gamma-inducible marker of prolonged immune activation, did not display significant differences between LS-associated and sporadic MSI CRCs [60,61]. However, Pfuderer et al. found much higher densities of high endothelial venules (HEV) in peritumoral tissue adjacent to hereditary MSI CRCs than to sporadic MSI CRCs [62]. HEVs are specialized postcapillary venules responsible for lymphocyte trafficking $[62,63]$. The evidence for enhanced lymphocyte recruitment to LS-associated 
MSI CRCs may point towards pre-existing immune responses in hereditary MSI patients induced by MMR-DCF [42]. Thus, long before tumor manifestation, MMR-DCF may prime the immune system of LS carriers against specific cMS mutation-induced FSP neoantigens. This is supported by the observation of FSP-specific immune responses in the peripheral blood of tumor-free LS carriers [64]. A primed immune system may facilitate strong immune infiltration of manifest cancers in the setting of LS but not, or only to a lesser degree, in sporadic MSI cancers.

\subsection{Immune Infiltration in Hereditary and Sporadic ECs}

The phenomenon of enhanced immune responses associated with the hereditary origin of MSI cancer is not restricted to the colon. A study by Pakish et al. (2017) showed that a trend towards elevated immune cell infiltration can also be observed in LS-associated MSI ECs. The stromal compartments of LS-associated ECs displayed a significantly higher number of CD8-positive T cells, compared to the sporadic controls. In addition, higher CD8-positive intraepithelial T cell counts were observed in LS-associated ECs, but this increase did not reach statistical significance [52]. Similarly, Ramchander et al. reported a significantly elevated number of CD8-positive $\mathrm{T}$ cells in the invasive margin of LS-associated MSI ECs compared to sporadic cases. The same tendency was observed in the tumor center but failed to reach statistical significance [53]. Furthermore, another study reported a higher frequency of PD-L1 expression in LS-associated MSI ECs, compared to sporadic MSI ECs [65]. Ultimately, the picture of immune responses in LS-associated and sporadic MSI CRCs may go beyond tumor- and adenoma-related immune infiltration, as systemic immune responses against FSP neoantigens have been detected in tumor-free LS mutation carriers [64]. This finding may point at tumor-independent differences in the immune phenotype between the general population and LS carriers being present long before tumor manifestation and possibly influencing cancer risk in LS carriers. Such systemic immune responses might be linked to LS-associated MMR-deficient lesions, which can be detected not only in colorectal [40,41] but also in the endometrial tissue of LS carriers [66].

\subsection{Immune Evasion Mechanisms in Hereditary and Sporadic MSI CRCS}

Pronounced immune infiltration and strong local immune response can exert a substantial selective pressure on emerging precancerous cell clones [67]. This can trigger immune evasion through positive selection of tumor cell clones capable to escape destruction via the immune system. The main immune evasion mechanism in MSI CRCs is impairment of HLA class I-mediated antigen presentation, present in approximately $70 \%$ of all MSI CRCs [13]. In MSI CRCs, HLA class I-mediated antigen presentation is most frequently abrogated by mutations in the B2M (Beta-2 microglobulin) gene, which is affected in 30\% of MSI CRCs. The B2M gene contains four microsatellites in its coding region, which make this gene susceptible for mutation in MMR-deficient cells $[12,13,68,69]$. Interestingly, the observed frequency of $B 2 M$-inactivating mutations is significantly higher than expected by chance based on the short length of the microsatellites [70], illustrating the tremendous survival advantage of B2M-mutant MSI clones under immune surveillance. Moreover, B2M mutations are closely associated with active local immune responses, represented by high numbers of activated $\mathrm{T}$ cells and a high density of HEVs $[62,71]$.

Five studies were identified that could be analyzed regarding immune evasion mechanisms affecting HLA class I- and HLA class II-related antigen presentation in hereditary and sporadic MSI CRCs (Table 2). 
Table 2. Summary of publications analyzing immune evasion in LS-associated and sporadic MSI CRCs and adenomas, distinguishing between mutations of the HLA class I and HLA class II pathways. Numbers of used samples are indicated for all groups and percentages of mutated samples are shown. Asterisk represents statistically significant differences between the hereditary and sporadic group.

\begin{tabular}{|c|c|c|c|c|c|c|}
\hline & \multicolumn{2}{|c|}{ HLA I-B2M Mutations } & \multirow{2}{*}{\multicolumn{2}{|c|}{ Colorectal MSI Adenomas }} & \multicolumn{2}{|c|}{ LS Status } \\
\hline & $\begin{array}{l}\text { Hereditary MSI } \\
\text { CRCs }\end{array}$ & $\begin{array}{l}\text { Sporadic MSI } \\
\text { CRCs }\end{array}$ & & & Proven & Suspected \\
\hline $\begin{array}{c}\text { Clendenning et al., } \\
2018 \text { [72] }\end{array}$ & $17.1 \%(7 / 41)$ & $29 \%(20 / 69)$ & \multicolumn{2}{|c|}{$0 \%(0 / 42)$} & $x$ & $\mathrm{x}$ \\
\hline $\begin{array}{l}\text { Dierssen et al., } \\
2006 \text { [73] }\end{array}$ & $20 \%(15 / 75)$ & $3 \%(1 / 33)$ & \multicolumn{2}{|c|}{$\mathrm{x}$} & $\mathrm{x}$ & \\
\hline $\begin{array}{l}\text { Janikovits et al., } \\
2018 \text { [47] }\end{array}$ & $50 \%(9 / 18)$ & $26.3 \%(10 / 38)$ & \multicolumn{2}{|c|}{$\mathrm{x}$} & $\mathrm{x}$ & \\
\hline $\begin{array}{c}\text { Kloor et al., } 2007 \\
\text { [12] }\end{array}$ & $36.4 \%(16 / 44)$ & $15.4 \%(4 / 26)$ & \multicolumn{2}{|c|}{$15.8 \%(6 / 38)$} & $x$ & \\
\hline Total & $35.9 \%(47 / 131)$ & $26.7 \%(35 / 131)$ & \multicolumn{2}{|c|}{$7.5 \%(6 / 80)$} & & \\
\hline $95 \% \mathrm{CI}$ & 0.2816 to 0.4440 & 0.1985 to 0.3491 & & & & \\
\hline \multirow[t]{4}{*}{$p$-value } & \multicolumn{2}{|c|}{0.1425} & & & & \\
\hline & \multicolumn{4}{|c|}{ HLA II-Mutations in CIITA and RFX5 } & & \\
\hline & \multicolumn{2}{|c|}{ CIITA } & \multicolumn{2}{|c|}{ RFX5 } & & \\
\hline & $\begin{array}{l}\text { Hereditary MSI } \\
\text { CRCs }\end{array}$ & $\begin{array}{l}\text { Sporadic MSI } \\
\text { CRCs }\end{array}$ & $\begin{array}{l}\text { Hereditary } \\
\text { MSI CRCs }\end{array}$ & $\begin{array}{l}\text { Sporadic } \\
\text { MSI CRCs }\end{array}$ & & \\
\hline $\begin{array}{l}\text { Surmann et al., } \\
2015 \text { [51] }\end{array}$ & $8.9 \%(3 / 35)$ & $0 \%(0 / 34)$ & $14.3 \%(5 / 35)$ & $26.5 \%(9 / 34)$ & & n.a. \\
\hline
\end{tabular}

Loss of HLA class I due to B2M mutations was examined in a total of 178 hereditary and 166 sporadic MSI CRCs. The proportion of B2M-mutated LS-associated MSI CRCs varied between $17 \%$ and $50 \%$. For sporadic MSI CRCs this proportion ranged between 3\% and $29 \%$. The majority of included studies reported a higher frequency of B2M mutations in hereditary MSI CRCs compared to sporadic cases $[12,47,73]$ (Figure 4). Only one study identified through our literature search [72] reported a higher rate of $B 2 M$ mutations in sporadic compared to LS-associated CRCs. Although the reasons for this discrepancy are not clear, the study by Clendenning et al. confirmed previous reports that $B 2 \mathrm{M}$ mutations are associated with increased immune infiltration and elevated numbers of Crohn's like lesions in the tumor vicinity, supporting the hypothesis of immunoediting as the cause of outgrowth of tumor cells with impaired B2M [72].

In addition, two studies analyzed the frequency of $B 2 M$ mutations in adenomas: Kloor et al. (2007) reported a $15.8 \%$ B2M mutation frequency in 38 MSI adenomas [12]. In contrast, Clendenning et al. did not observe any B2M mutations in 42 MMR-deficient adenomas [72]. Although the hereditary or sporadic origin of the analyzed adenomas was not clearly specified in these two studies, the current literature suggests high likelihood of MSI/MMR-deficient adenomas to be indicative of LS [74].

The frequency of $B 2 M$ mutations also seems to be influenced by the affected MMR gene, as a genomic and transcriptomic characterization of LS-associated CRCs revealed that MLH1-mutated tumors, compared to those having defects in the other MMR genes, may present with a higher rate of B2M mutations [75]. This observation potentially implies that MLH1-deficient tumors may be exposed to more pronounced immune responses than MSH2-deficient tumors. Similar findings have been reported independently by Clendenning et al. (2018) and Echterdiek et al. (2016) [71,72]. The mechanisms underlying this difference between MLH1- and MSH2-related immune phenotypes are not fully understood yet and require further research. 


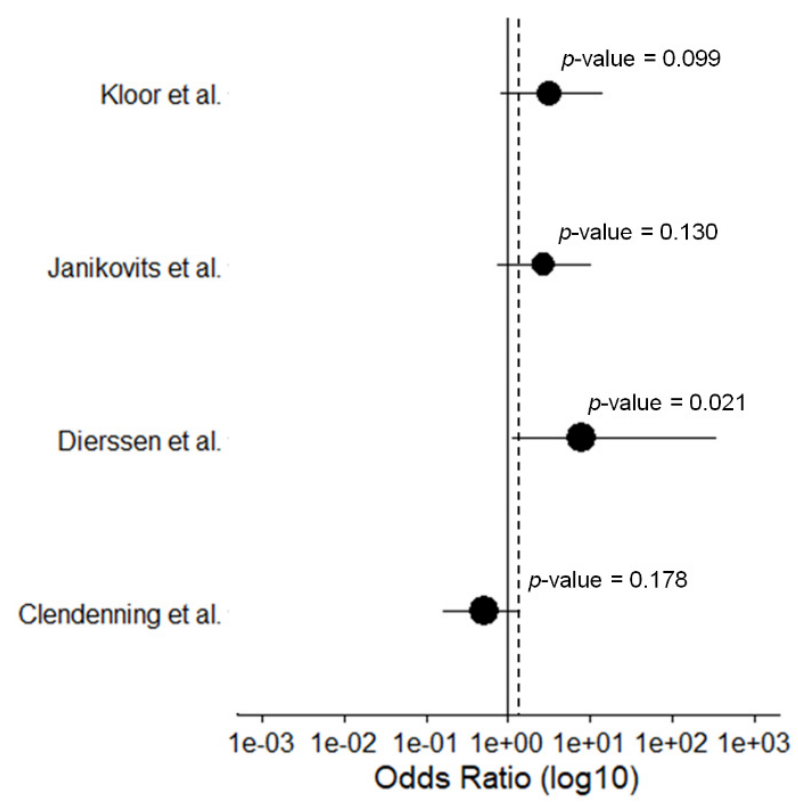

Figure 4. Forest plot of the calculated Odds Ratios for the B2M mutation frequency for hereditary vs. sporadic MSI CRCs with a 95\% CI. Datapoints are proportional to study size. The dashed line indicates the total Odds Ratio.

Further studies are also necessary to evaluate potential differences related to the HLA class II antigen presentation machinery, which may have an important role in MSI cancer immunology [76]. Mutations of components involved in the HLA class II antigen processing and presentation pathway have so far only been addressed by one study [51], which analyzed 35 hereditary and 34 sporadic MSI CRCs for CIITA and RFX5 mutations. Although not reaching statistical significance, potential differences were observed in the patterns of mutations in HLA class II-regulatory genes, as CIITA mutations were more frequent in hereditary MSI CRCs, whereas RFX5 mutations occurred more frequently in sporadic MSI CRCs [51].

\subsection{Response to Therapy in Hereditary and Sporadic MSI CRCS}

Long before the era of ICB treatment, differences in therapy response have been observed between MSI and MSS CRC patients. 5-Fluorouracil (5-FU) treatment demonstrated limited therapeutic effects in MSI CRC patients and has even been reported to be associated with detrimental effects [77-79]. Therefore, adjuvant 5-FU-based chemotherapy is not recommended for MSI CRC patients of UICC (Union for International Cancer Control) stage II. However, MSI CRC patients seem to respond well to irinotecan-based therapies [80,81]. The mechanisms responsible for these differences are not fully clear. Besides potential immune modulation by chemotherapy, MMR deficiency may directly influence responsiveness on the cellular level. A functional MMR system may be required for cell death induction after 5-FU integration [80], whereas irinotecan-induced impairment of DNA damage repair may be synthetically lethal in MMR-deficient cells. Only few studies so far analyzed chemotherapy responsiveness differentially between hereditary and sporadic MSI CRCs. Sinicrope et al. (2011) reported a significant reduction of distant recurrences and improved disease-free survival in LS-associated MSI CRC patients compared to sporadic MSI CRC patients, both groups receiving 5-FU-based chemotherapy [82]. In addition, a study by Zaanan et al. reported a significantly improved progression-free survival for patients with LS-associated MSI CRCs under chemotherapy plus anti-EGFR, compared to patients with sporadic MSI CRCs [83].

Recently, ICB therapy revolutionized the field of oncology by showing a tremendous success in metastasized (UICC stage IV) MSI tumors. Blockade of the PD-1 receptor, e.g., with Pembrolizumab, shows success in treating metastatic MSI cancers irrespective of the tissue of origin $[16,84,85]$. A phase 
II study conducted by Le et al. demonstrated enhanced responsiveness of MMR-deficient CRCs to Pembrolizumab treatment, in comparison to MSS CRCs [16]. However, little is known about potential differences between sporadic and hereditary MSI CRCs under ICB treatment. Differences between the immune phenotype of sporadic and hereditary MSI cancers would be of immediate clinical relevance for ICB therapy, because sporadic MSI cancers can be differentiated from hereditary MSI cancers by molecular tumor analysis. If one of the two groups showed preferential response to ICB, information about hereditary and sporadic origin may guide patient selection for treatment.

Based on the data reported above, two major implications of pathogenesis on ICB responsiveness are conceivable.On the one hand, LS-associated MSI CRCs, according to the performed literature search, show an elevated density of local immune cells compared to the sporadic group. Local tumor infiltration with cytotoxic $T$ cells has been reported as a prerequisite for ICB response [86,87]. Therefore, LS patients with MSI cancers may have a higher chance of having sufficient numbers of $\mathrm{T}$ cells present at the tumor site, which can be reactivated by ICB to attack tumor cells.

On the other hand, most of the studies reported above found a higher rate of impaired HLA class I-mediated antigen presentation, mainly caused by B2M mutations, in hereditary MSI CRCs. Therefore, the opposite constellation is reasonable to assume; LS-associated MSI CRCs may more frequently show upfront resistance towards ICB, which however might be masked by the generally favorable prognosis of patients with B2M-mutant tumors [12,69]. Although the reason for the latter observation is not yet fully clarified, different theories explaining this counter-intuitive association exist, including enhanced NK cell-mediated tumor killing or lower metastatic capacity due decreased platelet binding [2,88-90].

Le et al. found no significant difference in the objective response rate between the hereditary and sporadic patient group receiving PD-1 blockade therapy, possibly because positive and negative factors offset each other $[16,17]$. The scarce data on differential responsiveness of MSI cancer patients based on hereditary or sporadic pathogenesis clearly indicates that future studies with systematic classification of patients according to the origin of the tumor will be necessary. Moreover, information about immune infiltration and immune evasion phenomena needs to be recorded for tumors treated by ICB.

\subsection{Alternative Explanations for Differing Immune Phenotypes}

In addition to the hypothesis of immune stimulation via FSP neoantigens prior to tumor development in LS setting, other explanation for the observed immunological differences should be considered, such as host factors that shape the immune system and respective immune responses. Recently, the importance of the host's immune status in the LS setting has been highlighted by a study showing that an immune dysfunction due to immunosuppression or autoimmune conditions is associated with a higher rate of multiple cancers [91]. This association underlines the major role of immune surveillance in determining LS cancer risk and indicates the necessity accounting for the immune status of LS carriers when performing cancer risk estimation studies.

LS-associated MSI cancers have a younger average age of onset than sporadic MSI cancers [27,92]. As the activity of the immune system and probably its capacity to recognize tumor cells are related to age [93-95], one may speculate that the observed elevated immune responses in LS mutation carriers compared to sporadic MSI tumor patients may merely reflect the generally younger age of the former. However, the local immune activation reflected in the HEV density and detected specifically in LS-associated tumors remained significantly higher than in sporadic MSI tumors even after correction for age [62], indicating that age alone cannot explain the enhanced local immune responses against LS-associated compared to sporadic MSI CRCs.

Additionally, gender should be taken into account when discussing the differences between hereditary and sporadic MSI CRCs as sporadic MSI CRCs predominantly occur in women. This is also reflected by the gender-specific differences in tumor location, molecular characteristics and mortality of CRCs [96]. Right-sided CRCs occur more frequently in women than in men [97]. In addition, the MSI tumor phenotype is also more common in women and a link to estrogen exposure could be made. 
Especially older, menopausal women with lowered estrogen levels are at risk to develop sporadic MSI CRCs, and it has been shown that hormone replacement therapy reduces the risk for MSI CRCs $[98,99]$. Females also present with a higher incidence of $B R A F$ mutations associated with sporadic MSI cancers as a consequence of age-related enhanced levels of DNA methylation and silencing of tumor-suppressor genes responsible for oncogene-induced senescence [96,100].

Besides being involved in tumorigenesis, BRAF mutations are also associated with immunosuppression [101-104]. As the BRAF V600E mutation very rarely occurs in LS-associated CRCs (1.4\%) but is displayed by around 64\% of sporadic MSI CRCs with MLH1 methylation [105], the proposed immunosuppressive features of this mutation have to be considered when comparing local immune responses in the two MSI CRC groups. However, the majority of studies reporting immunosuppressive effects of $B R A F$ mutations were done in melanoma and some additional evidence points to the absence of BRAF-mediated immunosuppression in the context of MSI CRCs: First, TIL density is not significantly reduced in BRAF-mutated MSI CRCs, compared to BRAF-wild-type MSI CRCs [106]. Second, BRAF-mutated MSI CRCs responded to ICB treatment with Nivolumab plus Ipilimumab as well as BRAF-wild-type MSI CRCs [84]. Third, BRAF mutation in the MSI setting is not associated with poorer prognosis and reduced overall survival, in contrast to MSS CRCs [107].

It is worthwhile to note that studies analyzed in this systematic literature review were heterogenous with regard to the definition of LS: whereas some studies only included proven pathogenic MMR variant carriers, others relied on LS definitions based on immunohistochemistry or fragment length analysis suggestive of the MMR-deficient/MSI phenotype, complemented by MLH1 methylation/BRAF mutation analysis and clinical criteria. Omitting such studies would have substantially reduced the comprehensiveness of our survey. As the percentage of tumors wrongly classified using the "suspected LS" classifier is expected to be low based on existing literature data, we decided to include both types of studies. Future studies addressing the immunological differences between sporadic and LS-associated MSI tumors are encouraged to define LS based on pathogenic MMR variants in the germline.

\section{Summary}

Our systematic literature analysis has two major findings: First, MSI cancers developing in the context of LS show more active local immune responses than sporadic MSI cancers. Second, and possibly related to the first finding, immune evasion phenomena in MSI cancers seem to be associated predominantly with a LS background. We found evidence that recurrent encounters with premalignant lesions prime the immune system against MSI-associated tumor antigens in LS individuals (Figure 5). Possibly, elevated immune surveillance is responsible for the incomplete penetrance of LS. However, to verify these hypotheses and gain more confidence in the general character of the findings currently based on CRC and EC, studies analyzing immunological features in other MSI tumors of the LS spectrum are warranted.

Our study demonstrates that classification of a tumor as MSI is insufficient to inform about its immunological phenotype and to predict response to immune therapy. With the advent of ICB as a powerful modality to treat advanced-stage MSI cancer patients, however lacking predictors of therapy success among MSI cancer patients, systematic characterization of (1) hereditary or sporadic origin, (2) immune infiltration and (3) immune evasion phenomena has become paramount in order to better delineate the determinants of therapy response. In particular, literature data suggesting differences with regard to immune evasion phenotypes between hereditary and sporadic MSI CRCs may point towards differential responsiveness to ICB. Although potentially being associated with additional costs and logistical hurdles, it is strongly encouraged to account for germline variant status and tumor immune status in future clinical studies addressing ICB in MSI cancer patients.

The findings of our study also have implications on tumor prevention. If immune surveillance governs MSI cancer evolution, modulation of immune surveillance may well hold the key towards effective prevention of MSI tumors, possibly by vaccination with shared MSI-induced FSP neoantigens. 
Hereditary origin

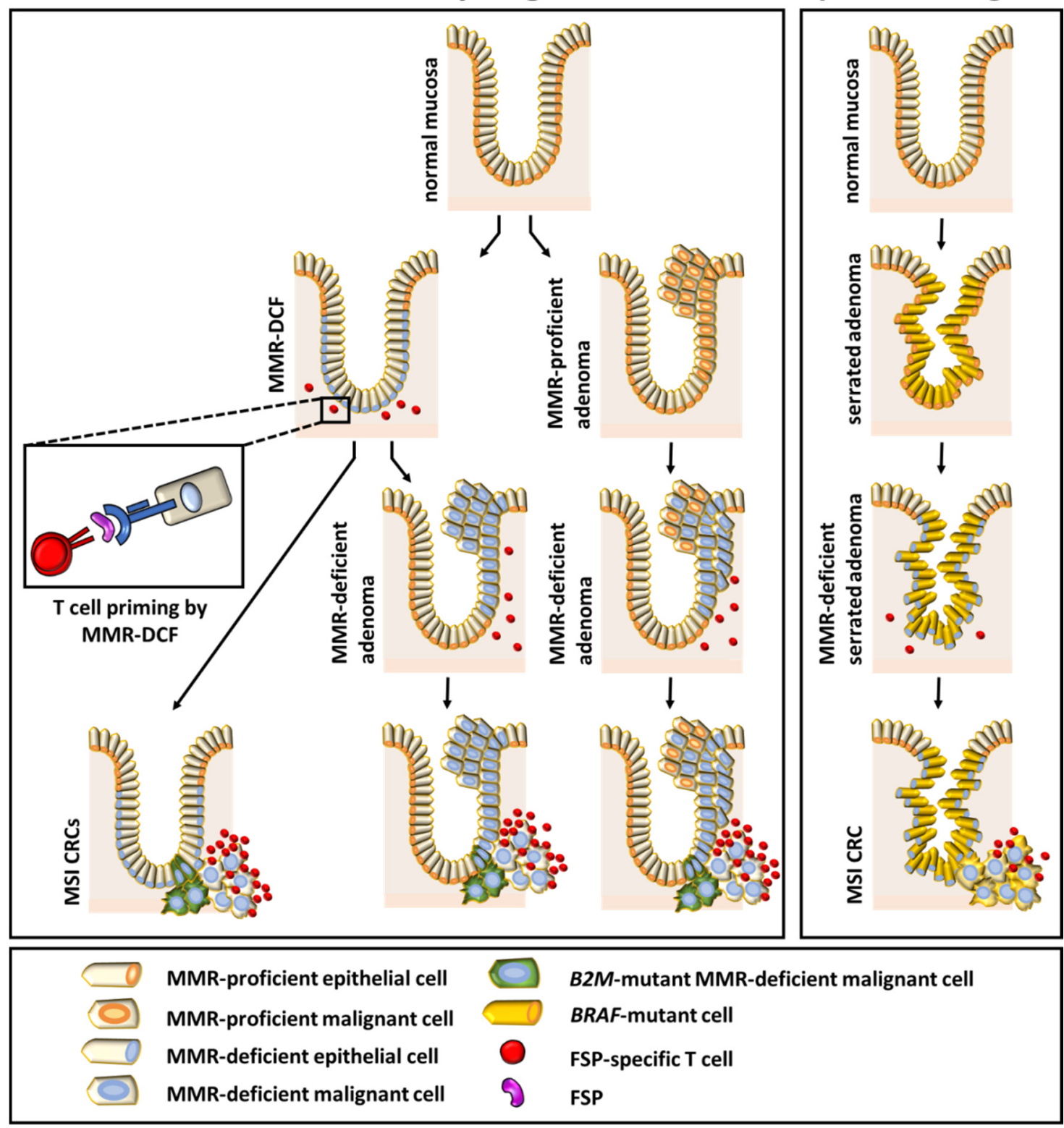

Figure 5. Summary figure showing the relationship between different colonic precursor lesions and the immune phenotype of the manifest tumor.

Supplementary Materials: The following are available online at http://www.mdpi.com/2077-0383/9/6/1741/s1. Table S1: List of papers that were excluded based on the full text during the systematic literature search. Reasons for exclusion are given.

Author Contributions: Conceptualization and methodology, L.B., M.v.K.D., M.K. and A.A.; formal analysis, L.B.; investigation and validation, M.K. and A.A.; resources and software, L.B.; data curation, L.B.; writing-original draft preparation and review and editing, L.B., M.v.K.D., M.K. and A.A.; visualization, L.B.; supervision, project administration and funding acquisition, M.v.K.D., M.K. and A.A. All authors have read and agreed to the published version of the manuscript.

Funding: This research study was supported by Else Kröner-Fresenius Foundation, 2018_A44.

Conflicts of Interest: The authors declare no conflict of interest. The funders had no role in the design of the study; in the collection, analyses or interpretation of data; in the writing of the manuscript or in the decision to publish the results. 


\section{References}

1. Hause, R.J.; Pritchard, C.C.; Shendure, J.; Salipante, S.J. Classification and characterization of microsatellite instability across 18 cancer types. Nat. Med. 2016, 22, 1342-1350. [CrossRef]

2. Kloor, M.; Von Knebel-Doeberitz, M. The immune biology of microsatellite unstable cancer. Trends Cancer 2016, 2, 121-133. [CrossRef]

3. Linnebacher, M.; Gebert, J.; Rudy, W.; Woerner, S.; Yuan, Y.P.; Bork, P.; Von Knebel Doeberitz, M. Frameshift peptide-derived T-cell epitopes: A source of novel tumor-specific antigens. Int. J. Cancer 2001, 93, 6-11. [CrossRef]

4. Saeterdal, I.; Gjertsen, M.K.; Straten, P.; Eriksen, J.A.; Gaudernack, G. A TFG $\beta R I I$ frameshift-mutation-derived CTL epitope recognised by HLA-A2-restricted CD8+T cells. Cancer Immunol. Immunother. 2001, 50, 469-476. [CrossRef] [PubMed]

5. Ripberger, E.; Linnebacher, M.; Schwitalle, Y.; Gebert, J.; Von Knebel Doeberitz, M. Identification of an HLA-A0201-restricted CTL epitope generated by a tumor-specific frameshift mutation in a coding microsatellite of the OGT gene. J. Clin. Immunol. 2003, 23, 415-423. [CrossRef] [PubMed]

6. Kloor, M.; Staffa, L.; Ahadova, A. Clinical significance of microsatellite instability in colorectal cancer. Langenbeck's Arch. Surg. 2014, 399, 23-31. [CrossRef] [PubMed]

7. Shia, J.; Holck, S.; DePetris, G.; Greenson, J.K.; Klimstra, D.S. Lynch syndrome-associated neoplasms: A discussion on histopathology and immunohistochemistry. Fam. Cancer 2013, 12, 241-260. [CrossRef]

8. Buckowitz, A.; Knaebel, H.-P.; Benner, A.; Bläker, H.; Gebert, J.; Kienle, P.; Von Knebel Doeberitz, M.; Kloor, M. Microsatellite instability in colorectal cancer is associated with local lymphocyte infiltration and low frequency of distant metastases. Br. J. Cancer 2005, 92, 1746-1753. [CrossRef]

9. Smyrk, T.C.; Watson, P.; Kaul, K.; Lynch, H.T. Tumor-Infiltrating Lymphocytes Are a Marker for Microsatellite Instability in Colorectal Carcinoma. Cancer 2001, 91, 2417-2422. [CrossRef]

10. Dolcetti, R.; Viel, A.; Doglioni, C.; Russo, A.; Guidoboni, M.; Capozzi, E.; Vecchiato, N.; Macrì, E.; Fornasarig, M.; Boiocchi, M. High prevalence of activated intraepithelial cytotoxic T lymphocytes and increased neoplastic cell apoptosis in colorectal carcinomas with microsatellite instability. Am. J. Pathol. 1999, 154, 1805-1813. [CrossRef]

11. Michael-Robinson, J.M. Tumour infiltrating lymphocytes and apoptosis are independent features in colorectal cancer stratified according to microsatellite instability status. Gut 2001, 48, 360-366. [CrossRef]

12. Kloor, M.; Michel, S.; Buckowitz, B.; Rüschoff, J.; Büttner, R.; Holinski-Feder, E.; Dippold, W.; Wagner, R.; Tariverdian, M.; Benner, A.; et al. Beta2-microglobulin mutations in microsatellite unstable colorectal tumors. Int. J. Cancer 2007, 121, 454-458. [CrossRef] [PubMed]

13. Ozcan, M.; Janikovits, J.; von Knebel Doeberitz, M.; Kloor, M. Complex pattern of immune evasion in MSI colorectal cancer. Oncoimmunology 2018, 7, e1445453. [CrossRef] [PubMed]

14. Benatti, P.; Gafà, R.; Barana, D.; Marino, M.; Scarselli, A.; Pedroni, M.; Maestri, I.; Guerzoni, L.; Roncucci, L.; Menigatti, M.; et al. Microsatellite instability and colorectal cancer prognosis. Clin. Cancer Res. 2005, 11, 8332-8340. [CrossRef]

15. Popat, S.; Hubner, R.; Houlston, R.S. Systematic Review of Microsatellite Instability and Colorectal Cancer Prognosis. J. Clin. Oncol. 2005, 23, 609-618. [CrossRef] [PubMed]

16. Le, D.T.; Uram, J.N.; Wang, H.; Bartlett, B.R.; Kemberling, H.; Eyring, A.D.; Skora, A.D.; Luber, B.S.; Azad, N.S.; Laheru, D.; et al. PD-1 Blockade in Tumors with Mismatch-Repair Deficiency. N. Engl. J. Med. 2015, 372, 2509-2520. [CrossRef] [PubMed]

17. Le, D.T.; Durham, J.N.; Smith, K.N.; Wang, H.; Bjarne, R.; Aulakh, L.K.; Lu, S.; Kemberling, H.; Wilt, C.; Brandon, S.; et al. Mismatch-repair deficiency predicts response of solid tumors to PD-1. Science 2017, 357, 409-413. [CrossRef]

18. Kane, M.F.; Loda, M.; Gaida, G.M.; Lipman, J.; Mishra, R.; Goldman, H.; Jessup, J.M.; Kolodner, R. Methylation of the hMLH1 promoter correlates with lack of expression of hMLH1 in sporadic colon tumors and mismatch repair-defective human tumor cell lines. Cancer Res. 1997, 57, 808-811. [CrossRef]

19. Cunningham, J.M.; Christensen, E.R.; Tester, D.J.; Burgart, L.J.; Thibodeau, S.N.; Roche, P.C. Hypermethylation of the hMLHl Promoter in Colon Cancer with Microsatellite Instability. Cancer Res. 1998, 58, 3455-3460. 
20. Veigl, M.L.; Kasturi, L.; Olechnowicz, J.; Ma, A.H.; Lutterbaugh, J.D.; Periyasamy, S.; Li, G.M.; Drummond, J.; Modrich, P.L.; Sedwick, W.D.; et al. Biallelic inactivation of hMLH1 by epigenetic gene silencing, a novel mechanism causing human MSI cancers. Proc. Natl. Acad. Sci. USA 1998, 95, 8698-8702. [CrossRef]

21. Thibodeau, S.N.; French, A.J.; Cunningham, J.M.; Tester, D.; Burgart, L.J.; Roche, P.C.; McDonnell, S.K.; Schaid, D.J.; Vockley, C.W.; Michels, V.V.; et al. Microsatellite instability in colorectal cancer: Different mutator phenotypes and the principal involvement of hMLH1. Cancer Res. 1998, 58, 1713-1718. [PubMed]

22. Herman, J.G.; Umar, A.; Polyak, K.; Graff, J.R.; Ahuja, N.; Issa, J.-P.J.; Markowitz, S.; Willson, J.K.V.; Hamilton, S.R.; Kinzler, K.W.; et al. Incidence and functional consequences of hMLH1 promoter hypermethylation in colorectal carcinoma. Proc. Natl. Acad. Sci. USA 1998, 95, 6870-6875. [CrossRef] [PubMed]

23. Boland, C.R.; Goel, A. Microsatellite Instability in Colorectal Cancer. Gastroenterology 2010, 138, $2073-2087$. [CrossRef] [PubMed]

24. Knudson, A.G. Mutation and cancer: Statistical study of retinoblastoma. Proc. Natl. Acad. Sci. USA 1971, 68, 820-823. [CrossRef] [PubMed]

25. Hampel, H.; Frankel, W.L.; Martin, E.; Arnold, M.; Khanduja, K.; Kuebler, P.; Nakagawa, H.; Sotamaa, K.; Prior, T.W.; Westman, J.; et al. Screening for the Lynch Syndrome (Hereditary Nonpolyposis Colorectal Cancer). N. Engl. J. Med. 2005, 352, 1851-1860. [CrossRef]

26. ten Broeke, S.W.; Brohet, R.M.; Tops, C.M.; van der Klift, H.M.; Velthuizen, M.E.; Bernstein, I.; Capellá Munar, G.; Gomez Garcia, E.; Hoogerbrugge, N.; Letteboer, T.G.W.; et al. Lynch Syndrome Caused by Germline PMS2 Mutations: Delineating the Cancer Risk. J. Clin. Oncol. 2015, 33, 319-325. [CrossRef]

27. Jasperson, K.W.; Tuohy, T.M.; Neklason, D.W.; Burt, R.W. Hereditary and Familial Colon Cancer. Gastroenterology 2010, 138, 2044-2058. [CrossRef]

28. Vilar, E.; Gruber, S.B. Microsatellite Instability in Colorectal Cancer. Nat. Rev. Clin. Oncol. 2010, 7, $153-162$. [CrossRef]

29. Liccardo, R.; De Rosa, M.; Izzo, P.; Duraturo, F. Novel implications in molecular diagnosis of lynch syndrome. Gastroenterol. Res. Pract. 2017, 2017. [CrossRef]

30. Giardiello, F.M.; Allen, J.I.; Axilbund, J.E.; Boland, C.R.; Burke, C.A.; Burt, R.W.; Church, J.M.; Dominitz, J.A.; Johnson, D.A.; Kaltenbach, T.; et al. Guidelines on genetic evaluation and management of lynch syndrome: A consensus statement by the us multi-society task force on colorectal cancer. Gastroenterology 2014, 147, 502-526. [CrossRef]

31. Dominguez-Valentin, M.; Sampson, J.R.; Seppälä, T.T.; ten Broeke, S.W.; Plazzer, J.P.; Nakken, S.; Engel, C.; Aretz, S.; Jenkins, M.A.; Sunde, L.; et al. Cancer risks by gene, age, and gender in 6350 carriers of pathogenic mismatch repair variants: Findings from the Prospective Lynch Syndrome Database. Genet. Med. 2020, 22, 15-25. [CrossRef] [PubMed]

32. Barrow, E.; Hill, J.; Evans, D.G. Cancer risk in Lynch Syndrome. Fam. Cancer 2013, 12, 229-240. [CrossRef] [PubMed]

33. Boland, C.R.; Thibodeau, S.N.; Hamilton, S.R.; Sidransky, D.; Eshleman, J.R.; Burt, R.W.; Meltzer, S.J.; Rodriguez-Bigas, M.A.; Fodde, R.; Ranzani, G.N.; et al. A National Cancer Institute Workshop on Microsatellite Instability for cancer detection and familial predisposition: Development of international criteria for the determination of microsatellite instability in colorectal cancer. Cancer Res. 1998, 58, 5248-5257. [CrossRef] [PubMed]

34. Umar, A.; Boland, C.R.; Terdiman, J.P.; Syngal, S.; De La Chapelle, A.; Rüschoff, J.; Fishel, R.; Lindor, N.M.; Burgart, L.J.; Hamelin, R.; et al. Revised Bethesda Guidelines for Hereditary Nonpolyposis Colorectal Cancer (Lynch Syndrome) and Microsatellite Instability. J. Natl. Cancer Inst. 2004, 96, 261-268. [CrossRef]

35. Bettington, M.; Walker, N.; Clouston, A.; Brown, I.; Leggett, B.; Whitehall, V. The serrated pathway to colorectal carcinoma: Current concepts and challenges. Histopathology 2013, 62, 367-386. [CrossRef]

36. Brenner, H.; Kloor, M.; Pox, C.P. Colorectal cancer. Lancet 2014, 383, 1490-1502. [CrossRef]

37. Jass, J.R. Pathology of Hereditary Nonpolyposis. Ann. N. Y. Acad. Sci. 1994, 14, 1631-1634.

38. Lynch, H.T.; Smyrk, T.; Jass, J.R. Hereditary nonpolyposis colorectal cancer and colonic adenomas: Aggressive adenomas? Semin. Surg. Oncol. 1995, 11, 406-410. [CrossRef]

39. Love, R.R. Adenomas are precursor lesions for malignant growth in nonpolyposis hereditary carcinoma of the colon and rectum. Surg. Gynecol. Obstet. 1986, 162, 8-12. 
40. Pai, R.K.; Dudley, B.; Karloski, E.; Brand, R.E.; O'callaghan, N.; Rosty, C.; Buchanan, D.D.; Jenkins, M.A.; Thibodeau, S.N.; French, A.J.; et al. DNA Mismatch Repair Protein Deficient Non-Neoplastic Colonic Crypts: A Novel Indicator of Lynch Syndrome. Mod. Pathol. 2018, 31, 1608-1618. [CrossRef]

41. Kloor, M.; Huth, C.; Voigt, A.Y.; Benner, A.; Schirmacher, P.; von Knebel Doeberitz, M.; Bläker, H. Prevalence of mismatch repair-deficient crypt foci in Lynch syndrome: A pathological study. Lancet Oncol. 2012, 13, 598-606. [CrossRef]

42. Staffa, L.; Echterdiek, F.; Nelius, N.; Benner, A.; Werft, W.; Lahrmann, B.; Grabe, N.; Schneider, M.; Tariverdian, M.; Von Knebel Doeberitz, M.; et al. Mismatch repair-deficient crypt foci in lynch syndrome-molecular alterations and association with clinical parameters. PLOS ONE 2015, 10, e0121980. [CrossRef] [PubMed]

43. Ahadova, A.; Gallon, R.; Gebert, J.; Ballhausen, A.; Endris, V.; Kirchner, M.; Stenzinger, A.; Burn, J.; von Knebel Doeberitz, M.; Bläker, H.; et al. Three molecular pathways model colorectal carcinogenesis in Lynch syndrome. Int. J. Cancer 2018, 143, 139-150. [CrossRef] [PubMed]

44. RStudio Team. RStudio: Integrated Development for R; RStudio Inc.: Boston, MA, USA, 2019.

45. Aragon, T.J. Epitools: Epidemiology Tools. Available online: https://CRAN.R-project.org/package=epitools (accessed on 8 May 2020).

46. Wickham, H. ggplot2: Elegant Graphics for Data Analysis; Springer: New York, NY, USA, 2016. Available online: https://CRAN.Rproject.org/package=epitools (accessed on 8 May 2020).

47. Janikovits, J.; Müller, M.; Krzykalla, J.; Körner, S.; Echterdiek, F.; Lahrmann, B.; Grabe, N.; Schneider, M.; Benner, A.; Von Knebel Doeberitz, M.; et al. High numbers of PDCD1 (PD-1)-positive T cells and B2M mutations in microsatellite-unstable colorectal cancer. Oncoimmunology 2018, 7, e1390640. [CrossRef] [PubMed]

48. Shia, J.; Ellis, N.A.; Paty, P.B.; Nash, G.M.; Qin, J.; Offit, K.; Zhang, X.-M.; Markowitz, A.J.; Nafa, K.; Guillem, J.G.; et al. Value of histopathology in predicting microsatellite instability in hereditary nonpolyposis colorectal cancer and sporadic colorectal cancer. Am. J. Surg. Pathol. 2003, 27, 1407-1417. [CrossRef] [PubMed]

49. Takemoto, N.; Konishi, F.; Yamashita, K.; Kojima, M.; Furukawa, T.; Miyakura, Y.; Shitoh, K.; Nagai, H. The Correlation of Microsatellite Instability and Tumor-infiltrating Lymphocytes in Hereditary Non-polyposis Colorectal Cancer (HNPCC) and Sporadic Colorectal Cancers: The Significance of Different Types of Lymphocyte Infiltration. Jpn. J. Clin. Oncol. 2004, 34, 90-98. [CrossRef]

50. Koornstra, J.J.; de Jong, S.; Boersma-van Eck, W.; Zwart, N.; Hollema, H.; de Vries, E.G.E.; Kleibeuker, J.H. Fas ligand expression in lynch syndrome-associated colorectal tumours. Pathol. Oncol. Res. 2009, 15, 399-406. [CrossRef]

51. Surmann, E.-M.; Voigt, A.Y.; Michel, S.; Bauer, K.; Reuschenbach, M.; Ferrone, S.; von Knebel Doeberitz, M.; Kloor, M. Association of high CD4-positive T cell infiltration with mutations in HLA class II-regulatory genes in microsatellite-unstable colorectal cancer. Cancer Immunol. Immunother. 2015, 64, 357-366. [CrossRef]

52. Pakish, J.B.; Zhang, Q.; Chen, Z.; Liang, H.; Chisholm, G.B.; Yuan, Y.; Mok, S.C.; Broaddus, R.R.; Lu, K.H.; Yates, M.S. Immune Microenvironment in Microsatellite-Instable Endometrial Cancers: Hereditary or Sporadic Origin Matters. Clin. Cancer Res. 2017, 23, 4473-4481. [CrossRef]

53. Ramchander, N.C.; Ryan, N.A.J.; Bolton, J.; Bosse, T.; Walker, T.D.J.; Harries, L.; Evans, D.G.; Crosbie, E.J. Distinct Immunological Landscapes Characterize Inherited and Sporadic Mismatch Repair Deficient Endometrial Cancer. Front. Immunol. 2020, 10, 3023. [CrossRef]

54. Young, J.; Simms, L.A.; Biden, K.G.; Wynter, C.; Whitehall, V.; Karamatic, R.; George, J.; Goldblatt, J.; Walpole, I.; Robin, S.-A.; et al. Features of Colorectal Cancers with High-Level Microsatellite Instability Occurring in Familial and Sporadic Settings Parallel Pathways of Tumorigenesis. Am. J. Pathol. 2001, 159, 2107-2116. [CrossRef]

55. Jass, J.R.; Walsh, M.D.; Barker, M.; Simms, L.A.; Young, J.; Leggett, B.A. Distinction between familial and sporadic forms of colorectal cancer showing DNA microsatellite instability. Eur. J. Cancer 2002, 38, 858-866. [CrossRef]

56. Wang, T.; Lee, L.H.; Vyas, M.; Zhang, L.; Ganesh, K.; Firat, C.; Segal, N.H.; Desai, A.; Hechtman, J.F. Colorectal carcinoma with double somatic mismatch repair gene inactivation: Clinical and pathological characteristics and response to immune checkpoint blockade. Mod. Pathol. 2019, 32, 1551-1562. [CrossRef] [PubMed] 
57. Tougeron, D.; Maby, P.; Elie, N.; Fauquembergue, É.; Le Pessot, F.; Cornic, M.; Sabourin, J.-C.; Michel, P.; Frébourg, T.; Latouche, J.-B. Regulatory T Lymphocytes Are Associated with Less Aggressive Histologic Features in Microsatellite-Unstable Colorectal Cancers. PLoS ONE 2013, 8, e61001. [CrossRef]

58. Meijer, T.W.H.; Hoogerbrugge, N.; Nagengast, F.M.; Ligtenberg, M.J.L.; Van Krieken, J.H.J.M. In Lynch syndrome adenomas, loss of mismatch repair proteins is related to an enhanced lymphocytic response. Histopathology 2009, 55, 414-422. [CrossRef]

59. Chang, K.; Taggart, M.W.; Reyes-Uribe, L.; Borras, E.; Riquelme, E.; Barnett, R.M.; Leoni, G.; San Lucas, F.A.; Catanese, M.T.; Mori, F.; et al. Immune Profiling of Premalignant Lesions in Patients With Lynch Syndrome. JAMA Oncol. 2018, 4, 1085-1092. [CrossRef]

60. Ahtiainen, M.; Wirta, E.V.; Kuopio, T.; Seppälä, T.; Rantala, J.; Mecklin, J.P.; Böhm, J. Combined prognostic value of CD274 (PD-L1)/PDCDI (PD-1) expression and immune cell infiltration in colorectal cancer as per mismatch repair status. Mod. Pathol. 2019, 32, 866-883. [CrossRef]

61. Lee, K.S.; Kwak, Y.; Ahn, S.; Shin, E.; Oh, H.-K.; Kim, D.-W.; Kang, S.-B.; Choe, G.; Kim, W.H.; Lee, H.S. Prognostic implication of CD274 (PD-L1) protein expression in tumor-infiltrating immune cells for microsatellite unstable and stable colorectal cancer. Cancer Immunol. Immunother. 2017, 66, 927-939. [CrossRef]

62. Pfuderer, P.L.; Ballhausen, A.; Seidler, F.; Stark, H.-J.; Grabe, N.; Frayling, I.M.; Ager, A.; Von Knebel Doeberitz, M.; Kloor, M.; Ahadova, A. High endothelial venules are associated with microsatellite instability, hereditary background and immune evasion in colorectal cancer. Br. J. Cancer 2019, 121, 395-404. [CrossRef]

63. Girard, J.-P.; Springer, T.A. High endothelial venules (HEVs): Specialized endothelium for lymphocyte migration. Immunol. Today 1995, 16, 449-457. [CrossRef]

64. Schwitalle, Y.; Kloor, M.; Eiermann, S.; Linnebacher, M.; Kienle, P.; Knaebel, H.P.; Tariverdian, M.; Benner, A.; von Knebel Doeberitz, M. Immune Response Against Frameshift-Induced Neopeptides in HNPCC Patients and Healthy HNPCC Mutation Carriers. Gastroenterology 2008, 134, 988-997. [CrossRef] [PubMed]

65. Sloan, E.A.; Ring, K.L.; Willis, B.C.; Modesitt, S.C.; Mills, A.M. PD-L1 Expression in Mismatch Repair-deficient Endometrial Carcinomas, Including Lynch Syndrome-associated and MLH1 Promoter Hypermethylated Tumors. Am. J. Surg. Pathol. 2017, 41, 326-333. [CrossRef] [PubMed]

66. McKenzie, R.; Scott, R.J.; Otton, G.; Scurry, J. Early changes of endometrial neoplasia revealed by loss of mismatch repair gene protein expression in a patient diagnosed with Lynch syndrome. Pathology 2016, 48, 78-80. [CrossRef]

67. Dunn, G.P.; Bruce, A.T.; Ikeda, H.; Old, L.J.; Schreiber, R.D. Cancer immunoediting: From immunosurveillance to tumor escape. Nat. Immunol. 2002, 3, 991-998. [CrossRef] [PubMed]

68. Kloor, M.; Michel, S.; Von Knebel Doeberitz, M. Immune evasion of microsatellite unstable colorectal cancers. Int. J. Cancer 2010, 127, 1001-1010. [CrossRef] [PubMed]

69. Tikidzhieva, A.; Benner, A.; Michel, S.; Formentini, A.; Link, K.-H.; Dippold, W.; von Knebel Doeberitz, M.; Kornmann, M.; Kloor, M. Microsatellite instability and Beta2-Microglobulin mutations as prognostic markers in colon cancer: Results of the FOGT-4 trial. Br. J. Cancer 2012, 106, 1239-1245. [CrossRef] [PubMed]

70. Woerner, S.M.; Yuan, Y.P.; Benner, A.; Korff, S.; Von Knebel Doeberitz, M.; Bork, P. SelTarbase, a database of human mononucleotide-microsatellite mutations and their potential impact to tumorigenesis and immunology. Nucleic Acids Res. 2010, 38, D682-D689. [CrossRef]

71. Echterdiek, F.; Janikovits, J.; Staffa, L.; Müller, M.; Lahrmann, B.; Frühschütz, M.; Hartog, B.; Nelius, N.; Benner, A.; Tariverdian, M.; et al. Low density of FOXP3-positive T cells in normal colonic mucosa is related to the presence of beta2-microglobulin mutations in Lynch syndrome-associated colorectal cancer. Oncoimmunology 2016, 5, e1075692. [CrossRef]

72. Clendenning, M.; Huang, A.; Jayasekara, H.; Lorans, M.; Preston, S.; O'Callaghan, N.; Pope, B.J.; Macrae, F.A.; Winship, I.M.; Milne, R.L.; et al. Somatic mutations of the coding microsatellites within the beta-2-microglobulin gene in mismatch repair-deficient colorectal cancers and adenomas. Fam. Cancer 2018, 17, 91-100. [CrossRef]

73. Dierssen, J.W.F.; de Miranda, N.F.C.C.; Mulder, A.; van Puijenbroek, M.; Verduyn, W.; Claas, F.H.J.; van de Velde, C.J.H.; Fleuren, G.J.; Cornelisse, C.J.; Corver, W.E.; et al. High-resolution analysis of HLA class I alterations in colorectal cancer. BMC Cancer 2006, 6. [CrossRef] 
74. Dabir, P.D.; Bruggeling, C.E.; van der Post, R.S.; Dutilh, B.E.; Hoogerbrugge, N.; Ligtenberg, M.J.L.; Boleij, A.; Nagtegaal, I.D. Microsatellite instability screening in colorectal adenomas to detect Lynch syndrome patients? A systematic review and meta-analysis. Eur. J. Hum. Genet. 2020, 28, 277-286. [CrossRef] [PubMed]

75. Binder, H.; Hopp, L.; Schweiger, M.R.; Hoffmann, S.; Jühling, F.; Kerick, M.; Timmermann, B.; Siebert, S.; Grimm, C.; Nersisyan, L.; et al. Genomic and transcriptomic heterogeneity of colorectal tumours arising in Lynch syndrome. J. Pathol. 2017, 243, 242-254. [CrossRef] [PubMed]

76. Seliger, B.; Kloor, M.; Ferrone, S. HLA class II antigen-processing pathway in tumors: Molecular defects and clinical relevance. Oncoimmunology 2017, 6, e1171447. [CrossRef] [PubMed]

77. Ribic, C.M.; Sargent, D.J.; Moore, M.J.; Thibodeau, S.N.; French, A.J.; Goldberg, R.M.; Hamilton, S.R.; Laurent-Puig, P.; Gryfe, R.; Shepherd, L.E.; et al. Tumor microsatellite-instability status as a predictor of benefit from fluorouracil-based adjuvant chemotherapy for colon cancer. N. Engl. J. Med. 2003, 349, $247-257$. [CrossRef] [PubMed]

78. Benson, A.B.; Schrag, D.; Somerfield, M.R.; Cohen, A.M.; Figueredo, A.T.; Flynn, P.J.; Krzyzanowska, M.K.; Maroun, J.; McAllister, P.; Van Cutsem, E.; et al. American Society of Clinical Oncology recommendations on adjuvant chemotherapy for stage II colon cancer. J. Clin. Oncol. 2004, 22, 3408-3419. [CrossRef]

79. Alwers, E.; Jansen, L.; Bläker, H.; Kloor, M.; Tagscherer, K.E.; Roth, W.; Boakye, D.; Herpel, E.; Grüllich, C.; Chang-Claude, J.; et al. Microsatellite instability and survival after adjuvant chemotherapy among stage II and III colon cancer patients: Results from a population-based study. Mol. Oncol. 2019, 14, 363-372. [CrossRef]

80. Jo, W.-S.; Carethers, J.M. Chemotherapeutic implications in microsatellite unstable colorectal cancer. Cancer Biomark. 2006, 2, 51-60. [CrossRef]

81. Sargent, D.J.; Marsoni, S.; Monges, G.; Thibodeau, S.N.; Labianca, R.; Hamilton, S.R.; French, A.J.; Kabat, B.; Foster, N.R.; Torri, V.; et al. Defective mismatch repair as a predictive marker for lack of efficacy of fluorouracil-based adjuvant therapy in colon cancer. J. Clin. Oncol. 2010, 28, 3219-3226. [CrossRef]

82. Sinicrope, F.A.; Foster, N.R.; Thibodeau, S.N.; Marsoni, S.; Monges, G.; Labianca, R.; Yothers, G.; Allegra, C.; Moore, M.J.; Gallinger, S.; et al. DNA mismatch repair status and colon cancer recurrence and survival in clinical trials of 5-fluorouracil-based adjuvant therapy. J. Natl. Cancer Inst. 2011, 103, 863-875. [CrossRef]

83. Zaanan, A.; Hunriques, J.; Cohen, R.; Sefrioui, D.; Evrard, C.; de la Fouchardiere, C.; Lecomte, T.; Aparicio, T.; Svrcek, M.; Taieb, J.; et al. Efficacy of Anti-EGFR in MSI Metastatic Colorectal Cancer Depending on Sporadic or Familial Orgin. Available online: https://academic.oup.com/jnci/advance-article/doi/10.1093/jnci/djaa072/ 5838189 (accessed on 8 May 2020).

84. Overman, M.J.; Lonardi, S.; Wong, K.Y.M.; Lenz, H.J.; Gelsomino, F.; Aglietta, M.; Morse, M.A.; Van Cutsem, E.; McDermott, R.; Hill, A.; et al. Durable clinical benefit with nivolumab plus ipilimumab in DNA mismatch repair-deficient/microsatellite instability-high metastatic colorectal cancer. J. Clin. Oncol. 2018, 36, 773-779. [CrossRef]

85. Yaghoubi, N.; Soltani, A.; Ghazvini, K.; Hassanian, S.M.; Hashemy, S.I. PD-1/PD-L1 blockade as a novel treatment for colorectal cancer. Biomed. Pharmacother. 2019, 110, 312-318. [CrossRef] [PubMed]

86. Jiang, P.; Gu, S.; Pan, D.; Fu, J.; Sahu, A.; Hu, X.; Li, Z.; Traugh, N.; Bu, X.; Li, B.; et al. Signatures of T cell dysfunction and exclusion predict cancer immunotherapy response. Nat. Med. 2018, 24, 1550-1558. [CrossRef] [PubMed]

87. Tumeh, P.C.; Harview, C.L.; Yearley, J.H.; Shintaku, I.P.; Taylor, E.J.M.; Robert, L.; Chmielowski, B.; Spasic, M.; Henry, G.; Ciobanu, V.; et al. PD-1 blockade induces responses by inhibiting adaptive immune resistance HHS Public Access. Nature 2014, 515, 568-571. [CrossRef] [PubMed]

88. Liao, N.S.; Bix, M.; Zijlstra, M.; Jaenisch, R.; Raulet, D. MHC class I deficiency: Susceptibility to natural killer (NK) cells and impaired NK activity. Science 1991, 253, 199-202. [CrossRef] [PubMed]

89. Jager, M.J.; Hurks, H.M.H.; Levitskaya, J.; Kiessling, R. HLA expression in uveal melanoma: There is no rule without some exception. Hum. Immunol. 2002, 63, 444-451. [CrossRef]

90. Reimers, M.S.; Bastiaannet, E.; Langley, R.E.; Van Eijk, R.; Van Vlierberghe, R.L.P.; Lemmens, V.E.P.; Van Herk-Sukel, M.P.P.; Van Wezel, T.; Fodde, R.; Kuppen, P.J.K.; et al. Expression of HLA class i antigen, aspirin use, and survival after a diagnosis of colon cancer. JAMA Intern. Med. 2014, 174, 732-739. [CrossRef]

91. Bari, S.; Wang, X.; Ajose, T.; Muzaffar, J. Characterization of Lynch syndrome (LS) associated cancers in patients with immune dysfunction. J. Clin. Oncol. 2019, 37, 1532. [CrossRef] 
92. Sinicrope, F.A.; Sargent, D.J. Clinical implications of microsatellite instability in sporadic colon cancers. Curr. Opin. Oncol. 2009, 21, 369-373. [CrossRef]

93. Weng, N. Aging of the Immune System: How Much Can the Adaptive Immune System Adapt? Immunity 2006, 24, 495-499. [CrossRef]

94. Goronzy, J.J.; Weyand, C.M. Immune aging and autoimmunity. Cell. Mol. Life Sci. 2012, 69, 1615-1623. [CrossRef]

95. Weyand, C.M.; Goronzy, J.J. Aging of the Immune System. Mechanisms and Therapeutic Targets. Ann. Am. Thorac. Soc. 2016, 13, S422-S428. [CrossRef] [PubMed]

96. Tsai, Y.-J.; Huang, S.-C.; Lin, H.-H.; Lin, C.-C.; Lan, Y.-T.; Wang, H.-S.; Yang, S.-H.; Jiang, J.-K.; Chen, W.-S.; Lin, T.; et al. Differences in gene mutations according to gender among patients with colorectal cancer. World J. Surg. Oncol. 2018, 16, 128. [CrossRef] [PubMed]

97. Benedix, F.; Kube, R.; Meyer, F.; Schmidt, U.; Gastinger, I.; Lippert, H. Comparison of 17,641 Patients With Right- and Left-Sided Colon Cancer: Differences in Epidemiology, Perioperative Course, Histology, and Survival. Dis. Colon Rectum 2010, 53, 57-64. [CrossRef] [PubMed]

98. Writing Group for the Women's Health Initiative Investigators WG for the WHI. Risks and Benefits of Estrogen Plus Progestin in Healthy Postmenopausal Women: Principal Results From the Women's Health Initiative Randomized Controlled Trial. JAMA J. Am. Med. Assoc. 2002, 288, 321-333. [CrossRef] [PubMed]

99. Slattery, M.L.; Potter, J.; Caan, B.; Edwards, S.; Coates, A.; Ma, K.N.; Berry, T.D.; Samowitz, W.S. Estrogens Reduce and Withdrawal of Estrogens Increase Risk of Microsatellite-Instability-positive Colon Cancer. Cancer Res. 2001, 61, 126-130. [PubMed]

100. Johnson, A.A.; Akman, K.; Calimport, S.R.G.; Wuttke, D.; Stolzing, A.; De Magalhães, J.P. The role of DNA methylation in aging, rejuvenation, and age-related disease. Rejuvenation Res. 2012, 15, 483-494. [CrossRef]

101. Davies, H.; Bignell, G.R.; Cox, C.; Stephens, P.; Edkins, S.; Clegg, S.; Teague, J.; Woffendin, H.; Garnett, M.J.; Bottomley, W.; et al. Mutations of the BRAF gene in human cancer. Nature 2002, 417, 949-954. [CrossRef]

102. Bond, C.E.; Whitehall, V.L.J. How the BRAF V600E Mutation Defines a Distinct Subgroup of Colorectal Cancer: Molecular and Clinical Implications. Gastroenterol. Res. Pract. 2018, 2018, 9250757. [CrossRef]

103. Petermann, K.B.; Rozenberg, G.I.; Zedek, D.; Groben, P.; McKinnon, K.; Buehler, C.; Kim, W.Y.; Shields, J.M.; Penland, S.; Bear, J.E.; et al. CD200 is induced by ERK and is a potential therapeutic target in melanoma. J. Clin. Investig. 2007, 117, 3922-3929. [CrossRef]

104. Sumimoto, H.; Imabayashi, F.; Iwata, T.; Kawakami, Y. The BRAF-MAPK signaling pathway is essential for cancer-immune evasion in human melanoma cells. J. Exp. Med. 2006, 203, 1651-1656. [CrossRef]

105. Parsons, M.T.; Buchanan, D.D.; Thompson, B.; Young, J.P.; Spurdle, A.B. Correlation of tumour BRAF mutations and MLH1 methylation with germline mismatch repair (MMR) gene mutation status: A literature review assessing utility of tumour features for MMR variant classification. J. Med. Genet. 2012, 49, 151-157. [CrossRef] [PubMed]

106. Li, W.Q.; Kawakami, K.; Ruszkiewicz, A.; Bennett, G.; Moore, J.; Iacopetta, B. BRAF mutations are associated with distinctive clinical, pathological and molecular features of colorectal cancer independently of microsatellite instability status. Mol. Cancer 2006, 5, 2. [CrossRef] [PubMed]

107. Phipps, A.I.; Buchanan, D.D.; Makar, K.W.; Burnett-Hartman, A.N.; Coghill, A.E.; Passarelli, M.N.; Baron, J.A.; Ahnen, D.J.; Win, A.K.; Potter, J.D.; et al. BRAF mutation status and survival after colorectal cancer diagnosis according to patient and tumor characteristics. Cancer Epidemiol. Prev. Biomark. 2012, 21, 1792-1798. [CrossRef] [PubMed]

(C) 2020 by the authors. Licensee MDPI, Basel, Switzerland. This article is an open access article distributed under the terms and conditions of the Creative Commons Attribution (CC BY) license (http://creativecommons.org/licenses/by/4.0/). 